\title{
A study of oxy-coal combustion with steam addition and biomass blending by thermogravimetric analysis
}

\author{
M.V. Gil, J. Riaza, L. Álvarez, C. Pevida, J.J. Pis, F. Rubiera* \\ Instituto Nacional del Carbón, CSIC, Apartado 73, 33080 Oviedo, Spain
}

\begin{abstract}
The thermal characteristics of pulverized coal have been studied under oxy-fuel combustion conditions using non-isothermal thermogravimetric analysis. The atmospheres used were $21 \% \mathrm{O}_{2} / 79 \% \mathrm{~N}_{2}, \quad 21 \% \mathrm{O}_{2} / 79 \% \mathrm{CO}_{2}, \quad 30 \% \mathrm{O}_{2} / 70 \% \quad \mathrm{O}_{2}$ and $35 \% \mathrm{O}_{2} / 65 \% \mathrm{CO}_{2}$. Coal blends of coal with 10 and $20 \%$ of biomass were also studied under these atmospheres. The addition of 10 and $20 \%$ of steam was evaluated for the oxy-fuel combustion atmospheres with 21 and $30 \%$ of $\mathrm{O}_{2}$ in order to study the effect of the wet recirculation of flue gas. The results obtained were similar for all the different rank coals and indicated that replacing $\mathrm{N}_{2}$ by $\mathrm{CO}_{2}$ in the combustion atmosphere with $21 \%$ of $\mathrm{O}_{2}$ caused a slight decrease in the rate of mass loss and delayed the burning process of the coal, biomass and coal/biomass blend samples. When the $\mathrm{O}_{2}$ concentration was increased to 30 and $35 \%$ in the oxy-fuel combustion atmosphere, the rate of mass loss increased, the burning process occurred at lower temperatures and it was shorter in duration. An increase in the rate of mass loss and a reduction in burning time and temperature were observed after the addition of steam to the oxy-fuel combustion atmosphere. No relevant differences between the 10 and $20 \%$ steam concentrations were observed.
\end{abstract}

\footnotetext{
* Corresponding author. Tel.: +34 985118 975; Fax: +34 985297662.

E-mail address: frubiera@incar.csic.es (F. Rubiera)
} 
Keywords: Oxy-fuel combustion; Pulverized coal; Biomass; Steam; TG

\section{Introduction}

Interest in coal as an energy source for the future has recently been revived due to the stability of its supply and its relatively low cost. For these reasons, it is likely that coal will occupy an important position in the energy mix in the foreseeable future $[1,2]$. However, the emissions of greenhouse gas carbon dioxide from coal-fired power plants are very high and their effect on global climate change has been acknowledged worldwide. Various strategies for their reduction and sequestration are under study, including improvements in the efficiency of existing power plants, the introduction of advanced combined cycle power plants and the capture and storage of $\mathrm{CO}_{2}$ [3].

Carbon capture and storage (CCS) is considered one of the most realistic options for reducing $\mathrm{CO}_{2}$ emissions from fossil fuel use, particularly from large-scale stationary power plants. The main problem, however, is that the combustion of fossil fuel in air leads to a diluted concentration of $\mathrm{CO}_{2}$ in the flue gas stream (typically $15 \%$ by volume), rendering it unsuitable for direct sequestration in a supercritical state by compression, a process which requires a high concentration of $\mathrm{CO}_{2}[4,5]$.

As an alternative, oxy-fuel combustion is considered as a promising new approach for $\mathrm{CO}_{2}$ capture. Oxy-fuel combustion technology involves the combustion of pulverized coal in a mixture of oxygen (as opposed to air) and recirculated flue gas (mainly $\mathrm{CO}_{2}$ and $\mathrm{H}_{2} \mathrm{O}$ ). The advantages of this approach are that it offers a way of avoiding the excessively high flame temperatures characteristic of fuel combustion in oxygen, carries the heat through the boiler, reduces the net volume of flue gas and substantially 
increases the concentration of carbon dioxide in the flue gas. A flue gas consisting mainly of $\mathrm{CO}_{2}(80-95 \%$ by volume) and water vapour is then generated. The water vapour can be easily removed by condensation, making it easier to purify the remaining $\mathrm{CO}_{2}[6]$.

The successful implementation of $\mathrm{O}_{2} / \mathrm{CO}_{2}$ technology in conventional pulverized coal boilers depends on a full understanding of the changes that result from replacing $\mathrm{N}_{2}$ with $\mathrm{CO}_{2}$ in the oxidizer stream [7]. Although many published works have focused on the oxy-fuel combustion process [8-12], the effect of adding steam to the oxy-fuel combustion atmosphere has hardly been studied [13].

Alternatively, biomass is a renewable fuel which can be used for reducing $\mathrm{CO}_{2}$ emissions. This source of energy is considered carbon neutral because the carbon dioxide released during biomass utilization is recycled as an integral part of the carbon cycle. The combination of oxy-fuel combustion with biomass could be used as a sink for $\mathrm{CO}_{2}$ and therefore more knowledge about cofiring coal and biomass under oxy-fuel conditions is needed [14].

Thermogravimetric analysis (TG) is one of the most common techniques used to rapidly investigate and compare thermal events during the combustion and pyrolysis of solid raw materials, such as coal, woods, etc. [15-22]. Although extrapolation to other devices at a larger scale cannot be performed directly, the information obtained from the combustion profiles in the TG could be used for an initial evaluation of the behaviour of the combustion on an industrial scale [23]. This would contribute to an understanding of coal combustion behaviour and prove very useful both from a fundamental viewpoint and for the comparison of samples [24]. 
In this work, thermogravimetric analysis (TG) was used in order to study the effect of replacing $\mathrm{N}_{2}$ with $\mathrm{CO}_{2}$ in a combustion atmosphere and of enhanced levels of $\mathrm{O}_{2}$ in an oxy-fuel combustion atmosphere upon the thermal characteristics of different rank coals and coal/biomass blends. Oxy-fuel combustion with steam addition was also evaluated in order to study the effect of the wet recirculation of flue gas.

\section{Materials and methods}

\subsection{Materials}

Ten coals of different rank [25] were used in this work: an anthracite (AC), a semianthracite (HVN), two medium-volatile bituminous coals (UM and SAA) and six highvolatile bituminous coals (DAB, SAB, M6N, BA, CAB and NZ). A biomass, olive waste $(\mathrm{OW})$, was also employed. The samples were ground and sieved to obtain a particle size fraction of $75-150 \mu \mathrm{m}$. The proximate analysis and the high heating value of the samples are presented in Table 1.

\subsection{Apparatus and procedure}

The techniques employed in this study were thermogravimetric analysis (TG) and derivative thermogravimetry (DTG). Non-isothermal TG was performed using a Setaram TAG24 analyser. Approximately $5 \mathrm{mg}$ of sample was used for each experiment. A small amount of sample and a slow heating rate were used to avoid heat transfer limitations and to minimize mass transfer effects. The samples were heated at a heating rate of $15^{\circ} \mathrm{C} \mathrm{min}^{-1}$ in different atmospheres from room temperature to $1000{ }^{\circ} \mathrm{C}$. The simulated air combustion atmosphere was $21 \% \mathrm{O}_{2} / 79 \% \mathrm{~N}_{2}$. Three $\mathrm{O}_{2} / \mathrm{CO}_{2}$ oxy-fuel combustion conditions were used $\left(21,30\right.$ and $35 \%$ of $\left.\mathrm{O}_{2}\right)$. The addition of 10 and $20 \%$ 
of steam (as a replacement for $\mathrm{CO}_{2}$ ) to an oxy-fuel combustion atmosphere containing 21 and $30 \%$ of $\mathrm{O}_{2}$ was also evaluated in order to study the effect of the wet recirculation of flue gas. The total flow rate of all the mixtures of gases was $150 \mathrm{~cm}^{3} \mathrm{~min}^{-1}$. The steam generator consisted of a $\mathrm{CEM}{ }^{\circledR}$ (Controlled Evaporator and Mixer), in which water and $\mathrm{O}_{2} / \mathrm{CO}_{2}$ were mixed and heated up to $175^{\circ} \mathrm{C}$. Liquid and mass flow controllers were used to control the flow rates of the water, $\mathrm{O}_{2}, \mathrm{CO}_{2}$ and $\mathrm{N}_{2}$. The derivative curves (DTG) of the samples were represented as a function of temperature.

\subsection{Determination of the combustion parameters}

From the combustion profiles, the following thermal parameters were calculated for characterizing the combustion process: initial temperature $\left(T_{\mathrm{i}}\right)$, final temperature $\left(T_{\mathrm{f}}\right)$, peak temperature $\left(T_{\text {peak }}\right)$, temperature corresponding to a conversion degree of $50 \%$ $\left(T_{50}\right)$, maximum rate of mass loss $\left(\mathrm{DTG}_{\max }\right)$, average rate of mass loss (Average DTG) and coal reactivity index $\left(\mathrm{R}_{\mathrm{C}}\right)$. The initial temperature $\left(T_{\mathrm{i}}\right)$ and the final temperature $\left(T_{\mathrm{f}}\right)$ were taken as the temperature values (after the initial loss of moisture) at which the rate of mass loss was $1 \% \mathrm{~min}^{-1}$. The peak temperature $\left(T_{\text {peak }}\right)$ corresponds to the temperature at which maximum rate of mass loss occurs [26]. The temperature value at the maximum rate of mass loss is usually considered inversely proportional to the reactivity and combustibility of the sample [27], whereas the maximum rate of mass loss is considered directly proportional to the reactivity of the sample [28]. The average rate of mass loss (Average DTG) is the ratio between the burnout fraction and time during the temperature range of initial to final temperature. The coal reactivity index $\left(R_{C}\right)$ was used to evaluate the burning performance of pulverized coal, defined as:

$R_{C}=1 / \mathrm{m}_{0}(\mathrm{dm} / \mathrm{dt})_{\max }$ 
where $(\mathrm{dm} / \mathrm{dt})_{\max }$ is the maximum combustion rate and $\mathrm{m}_{0}$ is the initial mass of ash free sample. It should be noted that the greater the $\mathrm{R}_{\mathrm{C}}$ value, the higher the combustion reactivity.

\section{Results and discussion}

\subsection{Combustion characteristics of pulverized coal under air and $\mathrm{O}_{2} / \mathrm{CO}_{2}$ atmospheres}

DTG curves for the AC, HVN, DAB and NZ coal samples under the different combustion and oxy-fuel combustion atmospheres are shown as example in Fig. 1. The DTG curves for the other coals (not represented) showed similar behaviour. From the combustion profiles (Fig. 1), it can be seen that coal combustion in the $\mathrm{O}_{2} / \mathrm{N}_{2}$ atmosphere differed from that in the $\mathrm{O}_{2} / \mathrm{CO}_{2}$ atmosphere at the same oxygen concentration (21\%). For all the coals studied in the $21 \% \mathrm{O}_{2} / 79 \% \mathrm{CO}_{2}$ atmosphere, the curves of mass loss rate shifted to higher temperatures in relation to those in the $21 \% \mathrm{O}_{2} / 79 \% \mathrm{~N}_{2}$ conditions. This implies that there was a delay in the burning process, which may have been due to the higher specific heat of $\mathrm{CO}_{2}$ compared to $\mathrm{N}_{2}$, leading to comparatively lower gas temperatures and in turn to a reduction of the fuel particle temperatures during oxy-fuel combustion in comparison to combustion in air. Li et al. [6] found lower rates of mass loss and higher burning times for a bituminous coal after replacing $\mathrm{N}_{2}$ with $\mathrm{CO}_{2}$ from an air atmosphere, indicating that the devolatilization rate of coal was lower under a $\mathrm{CO}_{2}$ atmosphere than under a $\mathrm{N}_{2}$ atmosphere. These authors thus concluded that replacing $\mathrm{N}_{2}$ with $\mathrm{CO}_{2}$ was unfavourable to coal combustion.

On the other hand, if the oxygen concentration was increased under the oxy-fuel combustion atmospheres $\left(30 \% \mathrm{O}_{2} / 70 \% \mathrm{CO}_{2}\right.$ and $\left.35 \% \mathrm{O}_{2} / 65 \% \mathrm{CO}_{2}\right)$, the DTG curves moved to lower temperatures, and the rate of mass loss increased whereas the burning 
time decreased in comparison to the values achieved in the $21 \% \mathrm{O}_{2} / 79 \% \mathrm{~N}_{2}$ combustion atmosphere (Fig. 1). This may be because a higher oxygen concentration enhances the devolatilization and combustion of coal samples. Under a lower oxygen concentration, the ignition of both the volatile matter and char would be retarded [8].

Table 2 summarizes the combustion parameters for the AC, HVN, DAB and NZ coals, whose results are similar to those of the other coals studied. It can be seen that the initial temperature, $T_{\mathrm{i}}$, for the coal samples was similar or slightly higher under oxy-fuel combustion atmosphere with $21 \%$ of $\mathrm{O}_{2}$ compared to air. However, $T_{\mathrm{i}}$ decreased as the $\mathrm{O}_{2}$ concentration increased in the $\mathrm{O}_{2} / \mathrm{CO}_{2}$ atmosphere. The same tendency is observed for the final temperature, $T_{\mathrm{f}}$, the peak temperature, $T_{\text {peak, }}$ and the temperature corresponding to a conversion degree of $50 \%, T_{50}$. In contrast, the Average DTG and DTG $_{\max }$ values followed the opposite tendency. They were slightly lower under the air atmosphere than under the oxy-fuel atmosphere containing $21 \%$ of $\mathrm{O}_{2}$, but they increased as the $\mathrm{O}_{2}$ concentration increased in the $\mathrm{O}_{2} / \mathrm{CO}_{2}$ atmosphere. Table 2 also shows that, in general, the coal reactivity index $\left(R_{C}\right)$ in the $21 \% \mathrm{O}_{2} / 79 \% \mathrm{CO}_{2}$ atmosphere was slightly lower than that in the $21 \% \mathrm{O}_{2} / 79 \% \mathrm{~N}_{2}$ atmosphere, but was higher in the $30 \% \mathrm{O}_{2} / 70 \% \mathrm{CO}_{2}$ and $35 \% \mathrm{O}_{2} / 65 \% \mathrm{CO}_{2}$ atmospheres, these two atmospheres showing similar values of coal reactivity.

If the characteristic temperatures for all the different rank coals are compared, the order is the following: $\mathrm{AC}>\mathrm{HVN}>\mathrm{UM}=\mathrm{BA}>\mathrm{SAB}=\mathrm{SAA} \geq \mathrm{DAB}>\mathrm{CAB} \geq \mathrm{M} 6 \mathrm{~N}>\mathrm{NZ}$. This order approximately coincides with that of coal rank (Table 1). 
3.2. Combustion characteristics of biomass and coal/biomass blends under air and $\mathrm{O}_{2} / \mathrm{CO}_{2}$ atmospheres

Fig. 2 shows the DTG curves for the biomass sample, OW, and the coal/biomass blends under the oxy-fuel combustion atmospheres. From the combustion profiles (Fig. 2), it can be seen that the combustion of the OW, $90 \% \mathrm{HVN}+10 \% \mathrm{OW}$ and $80 \% \mathrm{HVN}+20 \% \mathrm{OW}$ samples in the $\mathrm{O}_{2} / \mathrm{N}_{2}$ atmosphere differed from that of the $\mathrm{O}_{2} / \mathrm{CO}_{2}$ atmosphere at the same oxygen concentration (21\%). As in the case of the coals, in the $21 \% \mathrm{O}_{2} / 79 \% \mathrm{CO}_{2}$ atmosphere, the curves of mass loss rate shifted to higher temperatures in relation to those in the $21 \% \mathrm{O}_{2} / 79 \% \mathrm{~N}_{2}$ conditions, indicating that there was a delay in the combustion process. However, for the biomass and coal/biomass blend samples, when the oxygen concentration was increased under the oxy-fuel combustion atmospheres $\left(30 \% \mathrm{O}_{2} / 70 \% \mathrm{CO}_{2}\right.$ and $\left.35 \% \mathrm{O}_{2} / 65 \% \mathrm{CO}_{2}\right)$, the DTG curves moved to lower temperatures, the rate of mass loss increased and the burning time decreased with respect to the corresponding parameters in the $21 \% \mathrm{O}_{2} / 79 \% \mathrm{~N}_{2}$ combustion atmosphere.

Fig. 2 also shows that an initial mass loss occurred between $25-105^{\circ} \mathrm{C}$ for all the samples, due to moisture evaporation, after which two mass loss stages occurred in the OW and blend samples, compared to a one stage mass loss for the HVN sample (Fig.1). The second mass loss stage in the OW sample was possibly due to the release of volatiles and their combustion, while the final mass loss may have been due to char oxidation. In the case of the blends, the second mass loss was very small, due to the low proportion of biomass in the blend, the last peak closely resembling that of the coal sample, presumably because coal was the predominant component of the blend.

The combustion parameters for these samples are summarized in Table 3. In the case of the OW and blend samples, the parameters were calculated only taking into 
consideration the last mass loss stage, so that they could be then compared with those of the HVN coal sample. For all the combustion and oxy-fuel combustion atmospheres, it can be observed that the highest values of $T_{\mathrm{i}}, T_{\mathrm{f}}, T_{50}, \mathrm{DTG}_{\max }$ and Average DTG corresponded to the HVN samples, followed by those of the $90 \% \mathrm{HVN}+10 \% \mathrm{OW}$ and the $80 \% \mathrm{HVN}+20 \% \mathrm{OW}$ samples in that order. Small differences were found in the $T_{\text {peak }}$ and $R_{C}$ values of the samples. The addition of biomass to the coal caused a decrease in the combustion and oxy-fuel combustion temperatures. Biomass is a fuel with high reactivity and high volatile matter content (Table 1), which can lead to a faster reaction and to an improvement in the combustion behaviour of a coal in agreement with the results of other works $[18,29,30]$.

\subsection{Effects of steam addition upon the oxy-fuel combustion characteristics of pulverized} coal

Fig. 3 compares the DTG curves for the AC, HVN, DAB and NZ coal samples under the $21 \% \mathrm{O}_{2} / 79 \% \mathrm{CO}_{2}$ and $30 \% \mathrm{O}_{2} / 70 \% \mathrm{CO}_{2}$ oxy-fuel combustion atmospheres with those corresponding to the same atmosphere after the replacement of $\mathrm{CO}_{2}$ with 10 and $20 \%$ of steam. It can be observed that the addition of steam shifted the DTG curves to lower temperatures and generally caused an increase in the rate of mass loss and a decrease in combustion time with respect to those in the $21 \% \mathrm{O}_{2} / 79 \% \mathrm{CO}_{2}$ or $30 \% \mathrm{O}_{2} / 70 \% \mathrm{CO}_{2}$ oxyfuel combustion atmospheres, probably due to the fact that the specific heat capacity of $\mathrm{H}_{2} \mathrm{O}$ is lower than that of $\mathrm{CO}_{2}$ [31], as a result of which the combustion stage was brought forward. However, no relevant differences were observed from the addition of 10 and $20 \%$ of steam (Fig. 3 ). 


\section{Conclusions}

The different coals studied exhibited different combustion behaviours under $\mathrm{O}_{2} / \mathrm{CO}_{2}$ oxy-fuel conditions with respect to air combustion conditions. The coal, biomass and coal/biomass blend samples showed slightly higher reactivities under air compared to oxy-fuel conditions at the same $\mathrm{O}_{2}$ level, since the replacement of $\mathrm{O}_{2}$ by $\mathrm{CO}_{2}$ caused the rate of mass loss to decrease and the burning process occurred at higher temperatures. However, once the $\mathrm{O}_{2}$ concentration had been increased to 30 and $35 \%$ in the oxy-fuel combustion atmosphere, the rate of mass loss rose and the burning process was brought forward and shortened. The addition of biomass to coal caused a decrease in the combustion and oxy-fuel combustion temperatures. The replacement of 10 and $20 \%$ of $\mathrm{CO}_{2}$ with steam in the oxy-fuel combustion atmosphere of the coal resulted in an increase in the rate of mass loss and a decrease in the burning time, no significant differences being observed between the two steam concentrations.

\section{Acknowledgements}

The present study was carried out with financial support from the Spanish MICINN (Project PS- 120000-2005-2) co-financed by the European Regional Development Fund. L.A. and J.R. acknowledge funding from the CSIC JAE program, which was cofinanced by the European Social Fund, and the Asturias Regional Government (PCTI program), respectively.

\section{References}

[1] BP. 2009. BP Statistical Review of World Energy June 2009. http://www.bp.com (Last accessed: November 22th, 2010). 
[2] Buhre BJP, Elliott LK, Sheng CD, Gupta RP, Wall TF. Oxy-fuel combustion technology for coal-fired power generation. Prog Energy Combust Sci 2005;31:283-307.

[3] Bejarano PA, Levendis YA. Single-coal-particle combustion in $\mathrm{O}_{2} / \mathrm{N}_{2}$ and $\mathrm{O}_{2} / \mathrm{CO}_{2}$ environments. Combust Flame 2008;153:270-87.

[4] Rathnam RK, Elliott LK, Wall TF, Liu Y, Moghtaderi B. Differences in reactivity of pulverised coal in air $\left(\mathrm{O}_{2} / \mathrm{N}_{2}\right)$ and oxy-fuel $\left(\mathrm{O}_{2} / \mathrm{CO}_{2}\right)$ conditions. Fuel Process Technol 2009;90:797-802.

[5] Toftegaard MB, Brix J, Jensen PA, Glarbor P, Jensen AD. Oxy-fuel combustion of solid fuels. Prog Energy Combust Sci 2010;36:581-625.

[6] Li Q, Zhao C, Chen X, Wu W, Li Y. Comparison of pulverized coal combustion in air and in $\mathrm{O}_{2} / \mathrm{CO}_{2}$ mixtures by thermo-gravimetric analysis. J Anal Appl Pyrolysis 2009;85:521-8.

[7] Molina A, Shaddix CR. Ignition and devolatilization of pulverized bituminous coal particles during oxygen/carbon dioxide coal combustion. Proc Combust Inst 2007;31:1905-12.

[8] Huang X, Jiang X, Han X, Wang H. Combustion characteristics of fine- and miropulverized coal in the mixture of $\mathrm{O}_{2} / \mathrm{CO}_{2}$. Energy Fuels 2008;22:3756-62.

[9] Li X, Rathnam RK, Yu J, Wang Q, Wall T, Meesri C. Pyrolysis and combustion characteristics of an Indonesian Low-Rank Coal under $\mathrm{O}_{2} / \mathrm{N}_{2}$ and $\mathrm{O}_{2} / \mathrm{CO}_{2}$ conditions. Energy Fuels 2010;24:160-4.

[10] Liu H, Zailani R, Gibbs BM. Comparisons of pulverized coal combustion in air and in mixtures of $\mathrm{O}_{2} / \mathrm{CO}_{2}$. Fuel 2005;84:833-40.

[11] Várhegyi G, Szabó P, Jakab E, Till F. Mathematical modeling of char reactivity in Ar- $\mathrm{O}_{2}$ and $\mathrm{CO}_{2}-\mathrm{O}_{2}$ mixtures. Energy Fuels 1996;10:1208-14.

[12] Zhang L, Binner E, Qiao Y, Li C-Z. In situ diagnostics of Victorian brown coal combustion in $\mathrm{O}_{2} / \mathrm{N}_{2}$ and $\mathrm{O}_{2} / \mathrm{CO}_{2}$ mixtures in drop-tube furnace. Fuel 2010;89:2703-12.

[13] Nozaki T, Takano S, Kiga T, Omata K, Kimura N. Analysis of the flame formed during oxidation of pulverized coal by an $\mathrm{O}_{2}-\mathrm{CO}_{2}$ mixture. Energy 1997;22:199205.

[14] Arias B, Pevida C, Rubiera F, Pis JJ. Effect of biomass blending on coal ignition and burnout during oxy-fuel combustion. Fuel 2008;87:2753-9.

[15] Pis JJ, de la Puente G, Fuente E, Morán A, Rubiera F. A study of the self-heating of fresh and oxidized coals by differential thermal análisis. Thermochim Acta 1996;279:93-101.

[16] Rubiera F, Morán A, Martínez O, Fuente E, Pis JJ. Influence of biological desulphurisation on coal combustion performance. Fuel Process Technol 1997;52:165-73.

[17] Niu SL, Lu CM, Han KH, Zhao JL. Thermogravimetric analysis of combustion characteristics and kinetic parameters of pulverized coals in oxy-fuel atmosphere. J Therm Anal Calorim 2009;98:267-274.

[18] Arenillas A, Rubiera F, Pis JJ, Jones JM, Williams A. The effect of the textural properties of bituminous coal chars on NO emissions. Fuel 1999;78:1779-85.

[19] Jiang XM, Cui ZG, Han XX, Yu HL. Thermogravimetric investigation on combustion characteristics of oil shale and high sulphur coal mixture. $\mathrm{J}$ Therm Anal Calorim 2006;85:761-4. 
[20] Buryan P, Staff M. Pyrolysis of the waste biomass. J Therm Anal Calorim 2008;93:637-40.

[21] Mothé CG, de Miranda IC. Characterization of sugarcane and coconut fibers by thermal analysis and FTIR. J Therm Anal Calorim 2009;97:661-5.

[22] Slovák V, Taraba B. Effect of experimental conditions on parameters derived from TG-DSC measurements of low-temperature oxidation of coal. J Therm Anal Calorim 2010;101:641-6.

[23] Cumming JW, McLaughlin J. The thermogravimetric behaviour of coal. Thermochim Acta 1982;57:253-72.

[24] Rubiera F, Arenillas A, Arias B, Pis JJ. Modification of combustion behaviour and NO emissions by coal blending. Fuel Process Technol 2002;77:111-7

[25] ASTM Standard D 388. Standard Classification of Coals by Rank. 2005.

[26] Rubiera F, Arenillas A, Fuente E, Miles N, Pis JJ. Effect of the grinding behaviour of coal blends on coal utilisation for combustion. Powder Technol 1999;105:3516.

[27] Haykırı-Açma H. Combustion characteristics of different biomass materials. Energ Convers Manage 2003;44:155-62.

[28] Zheng JA, Koziński JA. Thermal events occurring during the combustion of biomass residue. Fuel 2000;79:181-92.

[29] Gil MV, Casal D, Pevida C, Pis JJ, Rubiera F. Thermal behaviour and kinetics of coal/biomass blends during co-combustion. Bioresource Technol 2010;101:56018.

[30] Kastanaki E, Vamvuka D. A comparative reactivity and kinetic study on the combustion of coal-biomass char blends. Fuel 2006;85:1186-93.

[31] Khare SP, Wall TF, Farida AZ, Liu Y, Moghtaderi B, Gupta RP. Factors influencing the ignition of flames from air-fired swirl pf burners retroffited to oxy-fuel. Fuel 2008;87:1042-9. 


\section{Figure captions}

Fig. 1. DTG curves for coal combustion under different atmospheres

Fig. 2. DTG curves for the combustion of biomass and coal/biomass blends under different atmospheres

Fig. 3. DTG curves for coal combustion under oxy-fuel atmospheres with 21 and $30 \%$ of $\mathrm{O}_{2}$ containing steam 
Table 1. Proximate analysis and high heating value of the coals

\begin{tabular}{|c|c|c|c|c|c|c|c|c|c|c|c|}
\hline Sample & $\mathrm{AC}$ & HVN & UM & SAA & DAB & SAB & M6N & $\mathrm{BA}$ & CAB & $\mathrm{NZ}$ & OW \\
\hline Origin & Spain & Spain & Mexico & $\begin{array}{l}\text { South } \\
\text { Africa }\end{array}$ & China & $\begin{array}{l}\text { South } \\
\text { Africa }\end{array}$ & Mexico & Spain & Colombia & $\begin{array}{c}\text { New } \\
\text { Zealand }\end{array}$ & Spain \\
\hline Rank & an & sa & $\mathrm{mvb}$ & $\mathrm{mvb}$ & hvb & hvb & hvb & hvb & hvb & hvb & --- \\
\hline \multicolumn{12}{|l|}{ Proximate Analysis $^{\mathrm{a}}$} \\
\hline Moisture content/wt.\% & 2.3 & 1.1 & 0.4 & 2.6 & 2.9 & 2.4 & 1.8 & 1.2 & 4.3 & 11.5 & 9.2 \\
\hline Ash/wt.\%, db & 14.2 & 10.7 & 21.1 & 14.9 & 10.9 & 15.0 & 30.2 & 6.9 & 4.4 & 2.9 & 7.6 \\
\hline V.M./wt.\%, db & 3.6 & 9.2 & 23.7 & 25.6 & 28.8 & 29.9 & 30.6 & 33.9 & 39.6 & 47.9 & 71.9 \\
\hline F.C. $/ w t . \%, \mathrm{db}^{\mathrm{b}}$ & 82.2 & 80.1 & 55.2 & 59.5 & 60.3 & 55.1 & 39.2 & 59.2 & 56.0 & 49.2 & 20.5 \\
\hline High heating value $/ \mathrm{kJ} \mathrm{kg}^{-1}, \mathrm{db}$ & 29160 & 31818 & 27826 & 27952 & 28825 & 27780 & 23057 & 33081 & 30965 & 27943 & 19905 \\
\hline
\end{tabular}

an: anthracite; sa: semi-anthracite; mvb: medium-volatile bituminous coal; hvb: high-volatile bituminous coal.

$\mathrm{db}$ : dry basis.

a The proximate analysis was conducted in a LECO TGA-601.

${ }^{b}$ Calculated by difference. 
Table 2. Combustion parameters of the coals under different atmospheres

\begin{tabular}{|c|c|c|c|c|c|c|c|c|}
\hline Sample & Atmosphere & $T_{\mathrm{i}} /{ }^{\circ} \mathrm{C}$ & $T_{\mathrm{f}} /{ }^{\circ} \mathrm{C}$ & $T_{\text {peak }} /{ }^{\circ} \mathrm{C}$ & $T_{50} /{ }^{\circ} \mathrm{C}$ & $\mathrm{DTG}_{\max } / \% \mathrm{~s}^{-1}$ & $\begin{array}{c}\text { Average } \\
\text { DTG } / \% \mathrm{~s}^{-1}\end{array}$ & $R_{C} / \% \mathrm{~kg}^{-1} \mathrm{~s}^{-1}$ \\
\hline \multirow[t]{4}{*}{$\mathrm{AC}$} & $21 \% \mathrm{O}_{2} / 79 \% \mathrm{~N}_{2}$ & 560 & 732 & 625 & 634 & 0.261 & 0.141 & 53996 \\
\hline & $21 \% \mathrm{O}_{2} / 79 \% \mathrm{CO}_{2}$ & 561 & 734 & 633 & 636 & 0.248 & 0.139 & 50849 \\
\hline & $30 \% \mathrm{O}_{2} / 70 \% \mathrm{CO}_{2}$ & 545 & 707 & 608 & 613 & 0.303 & 0.146 & 65117 \\
\hline & $35 \% \mathrm{O}_{2} / 65 \% \mathrm{CO}_{2}$ & 540 & 696 & 600 & 603 & 0.333 & 0.154 & 71177 \\
\hline \multirow[t]{4}{*}{ HVN } & $21 \% \mathrm{O}_{2} / 79 \% \mathrm{~N}_{2}$ & 482 & 644 & 567 & 566 & 0.301 & 0.149 & 60252 \\
\hline & $21 \% \mathrm{O}_{2} / 79 \% \mathrm{CO}_{2}$ & 484 & 650 & 570 & 569 & 0.287 & 0.147 & 55352 \\
\hline & $30 \% \mathrm{O}_{2} / 70 \% \mathrm{CO}_{2}$ & 470 & 627 & 547 & 547 & 0.358 & 0.157 & 78894 \\
\hline & $35 \% \mathrm{O}_{2} / 65 \% \mathrm{CO}_{2}$ & 465 & 616 & 540 & 539 & 0.392 & 0.163 & 77706 \\
\hline \multirow[t]{4}{*}{ DAB } & $21 \% \mathrm{O}_{2} / 79 \% \mathrm{~N}_{2}$ & 357 & 588 & 516 & 499 & 0.229 & 0.105 & 48817 \\
\hline & $21 \% \mathrm{O}_{2} / 79 \% \mathrm{CO}_{2}$ & 360 & 593 & 520 & 503 & 0.222 & 0.103 & 45983 \\
\hline & $30 \% \mathrm{O}_{2} / 70 \% \mathrm{CO}_{2}$ & 351 & 576 & 501 & 490 & 0.255 & 0.109 & 55768 \\
\hline & $35 \% \mathrm{O}_{2} / 65 \% \mathrm{CO}_{2}$ & 346 & 567 & 495 & 483 & 0.265 & 0.111 & 56410 \\
\hline \multirow[t]{4}{*}{$\mathrm{NZ}$} & $21 \% \mathrm{O}_{2} / 79 \% \mathrm{~N}_{2}$ & 293 & 504 & 410 & 405 & 0.267 & 0.104 & 49585 \\
\hline & $21 \% \mathrm{O}_{2} / 79 \% \mathrm{CO}_{2}$ & 294 & 506 & 411 & 405 & 0.260 & 0.103 & 49821 \\
\hline & $30 \% \mathrm{O}_{2} / 70 \% \mathrm{CO}_{2}$ & 288 & 497 & 406 & 400 & 0.293 & 0.105 & 57537 \\
\hline & $35 \% \mathrm{O}_{2} / 65 \% \mathrm{CO}_{2}$ & 283 & 486 & 395 & 393 & 0.399 & 0.107 & 73462 \\
\hline
\end{tabular}

$T_{\mathrm{i}}$ : initial temperature; $T_{\mathrm{f}}$ : final temperature; $T_{\text {peak }}$ : peak temperature; $T_{50}$ : temperature corresponding to a conversion degree of $50 \%$; $\mathrm{DTG}$ max maximum rate of mass loss; Average DTG: average rate of mass loss; $R_{C}$ : coal reactivity index. 
Table 3. Combustion parameters of the biomass and the coal/biomass blends under different atmospheres

\begin{tabular}{|c|c|c|c|c|c|c|c|c|}
\hline Atmosphere & Sample & $T_{\mathrm{i}} /{ }^{\circ} \mathrm{C}$ & $T_{\mathrm{f}} /{ }^{\circ} \mathrm{C}$ & $T_{\text {peak }}{ }^{\circ} \mathrm{C}$ & $T_{50} /{ }^{\circ} \mathrm{C}$ & $\mathrm{DTG}_{\max } / \% \mathrm{~s}^{-1}$ & $\begin{array}{c}\text { Average } \\
\text { DTG } / \% \mathrm{~s}^{-1}\end{array}$ & $R_{C} / \% \mathrm{~kg}^{-1} \mathrm{~s}^{-1}$ \\
\hline \multirow{4}{*}{$21 \% \mathrm{O}_{2} / 79 \% \mathrm{~N}_{2}$} & $\mathrm{HVN}$ & 482 & 644 & 567 & 566 & 0.301 & 0.149 & 60252 \\
\hline & $90 \% \mathrm{HVN}-10 \% \mathrm{OW}$ & 465 & 641 & 565 & 561 & 0.282 & 0.132 & 62291 \\
\hline & $80 \% \mathrm{HVN}-20 \% \mathrm{OW}$ & 455 & 623 & 559 & 546 & 0.278 & 0.129 & 58044 \\
\hline & OW & 367 & 520 & 475 & 302 & 0.118 & 0.064 & 24636 \\
\hline \multirow[t]{4}{*}{$21 \% \mathrm{O}_{2} / 79 \% \mathrm{CO}_{2}$} & $\mathrm{HVN}$ & 484 & 650 & 570 & 569 & 0.287 & 0.147 & 55352 \\
\hline & $90 \% \mathrm{HVN}-10 \% \mathrm{OW}$ & 469 & 645 & 570 & 564 & 0.264 & 0.130 & 54590 \\
\hline & $80 \% \mathrm{HVN}-20 \% \mathrm{OW}$ & 460 & 628 & 565 & 552 & 0.269 & 0.127 & 55948 \\
\hline & OW & 370 & 522 & 475 & 305 & 0.118 & 0.064 & 23807 \\
\hline \multirow{4}{*}{$30 \% \mathrm{O}_{2} / 70 \% \mathrm{CO}_{2}$} & $\mathrm{HVN}$ & 470 & 627 & 547 & 547 & 0.358 & 0.157 & 78894 \\
\hline & $90 \% \mathrm{HVN}-10 \% \mathrm{OW}$ & 453 & 619 & 545 & 542 & 0.337 & 0.142 & 69394 \\
\hline & $80 \% \mathrm{HVN}-20 \% \mathrm{OW}$ & 452 & 608 & 545 & 535 & 0.308 & 0.131 & 61221 \\
\hline & OW & 371 & 514 & 467 & 308 & 0.122 & 0.067 & 31640 \\
\hline \multirow[t]{4}{*}{$35 \% \mathrm{O}_{2} / 65 \% \mathrm{CO}_{2}$} & $\mathrm{HVN}$ & 465 & 616 & 540 & 539 & 0.392 & 0.163 & 77706 \\
\hline & $90 \% \mathrm{HVN}-10 \% \mathrm{OW}$ & 453 & 611 & 540 & 536 & 0.358 & 0.145 & 76386 \\
\hline & $80 \% \mathrm{HVN}-20 \% \mathrm{OW}$ & 448 & 601 & 535 & 529 & 0.335 & 0.137 & 65442 \\
\hline & OW & 365 & 509 & 461 & 302 & 0.129 & 0.067 & 25639 \\
\hline
\end{tabular}

$T_{\mathrm{i}}$ : initial temperature; $T_{\mathrm{f}}$ : final temperature; $T_{\text {peak }}$ : peak temperature; $T_{50}$ : temperature corresponding to a conversion degree of $50 \%$; DTG ${ }_{\text {max }}$ : maximum rate of mass loss; Average DTG: average rate of mass loss; $R_{C}$ : coal reactivity index. 

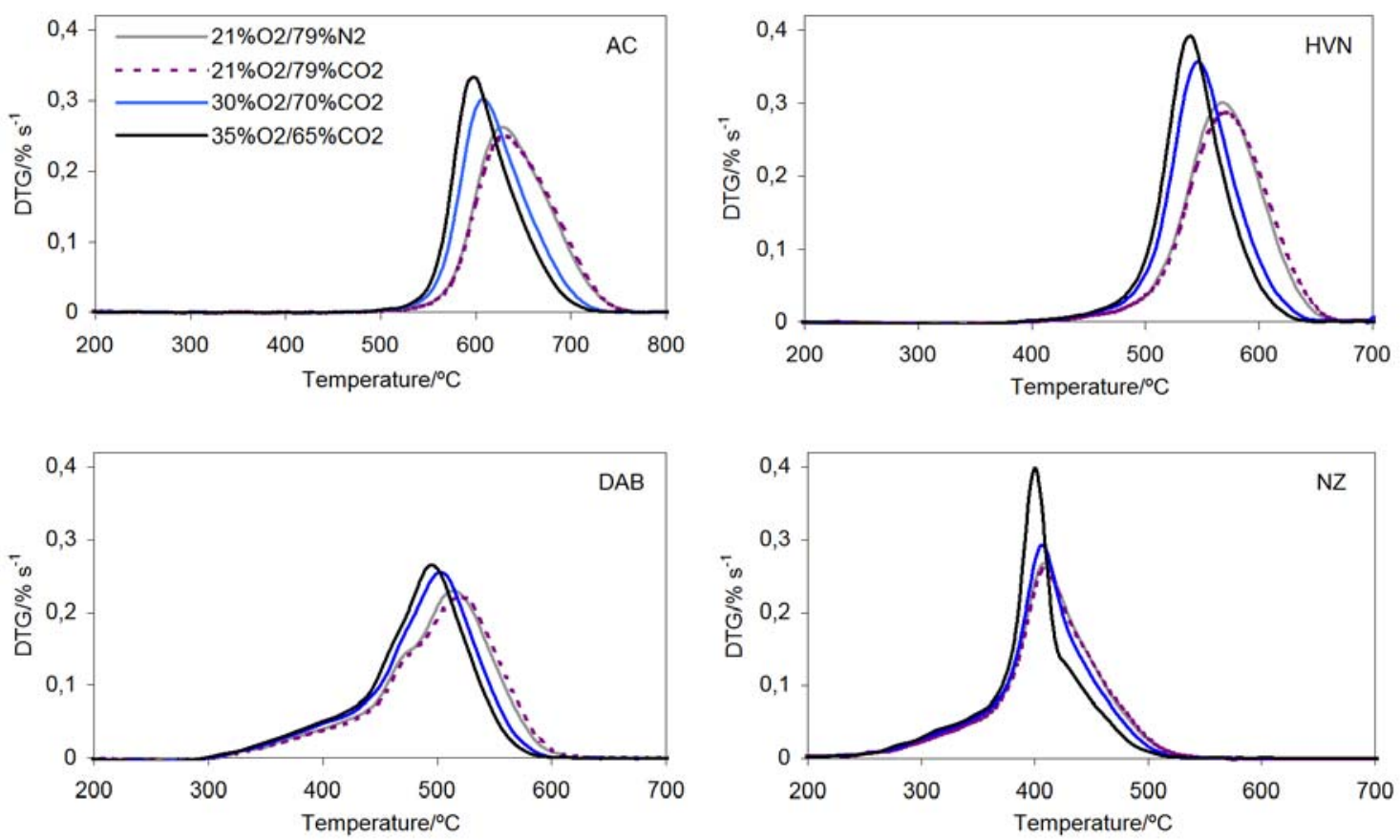

Fig. 1. DTG curves for coal combustion under different atmospheres 

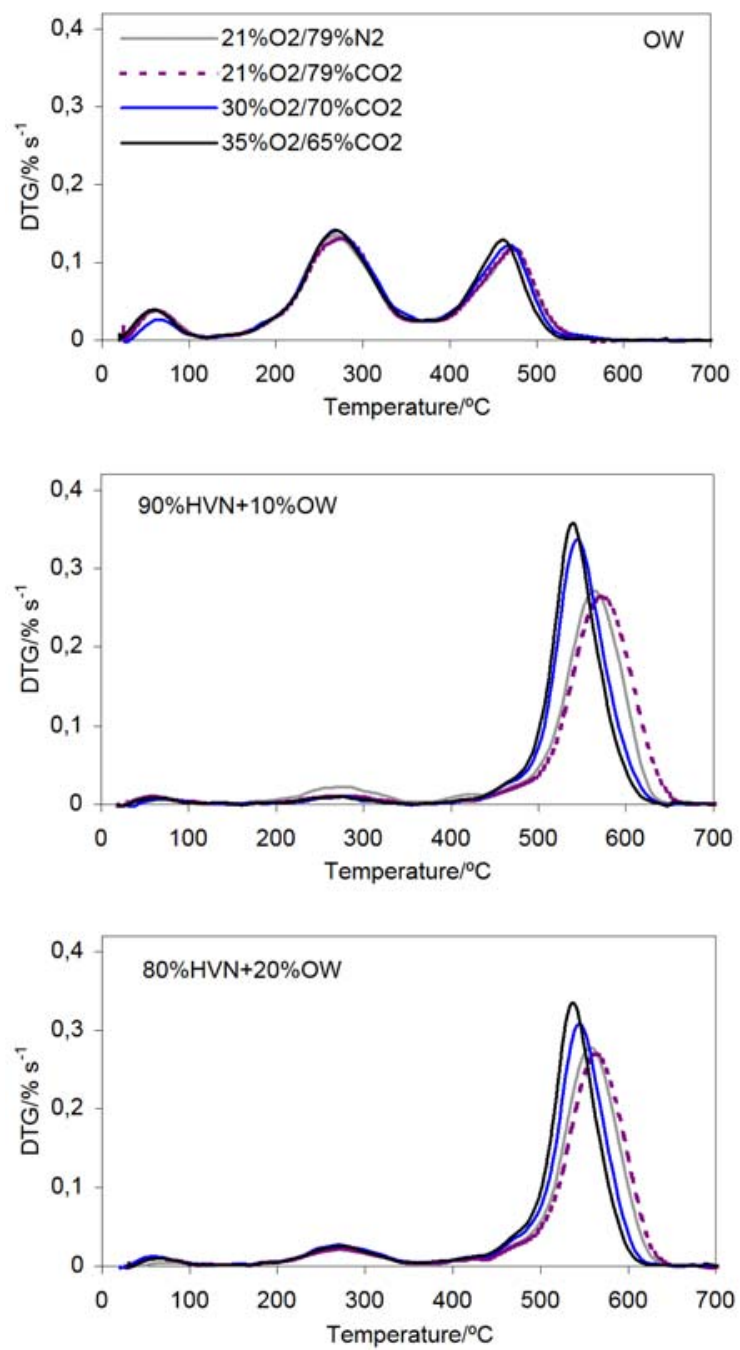

Fig. 2. DTG curves for the combustion of biomass and coal/biomass blends under different atmospheres 

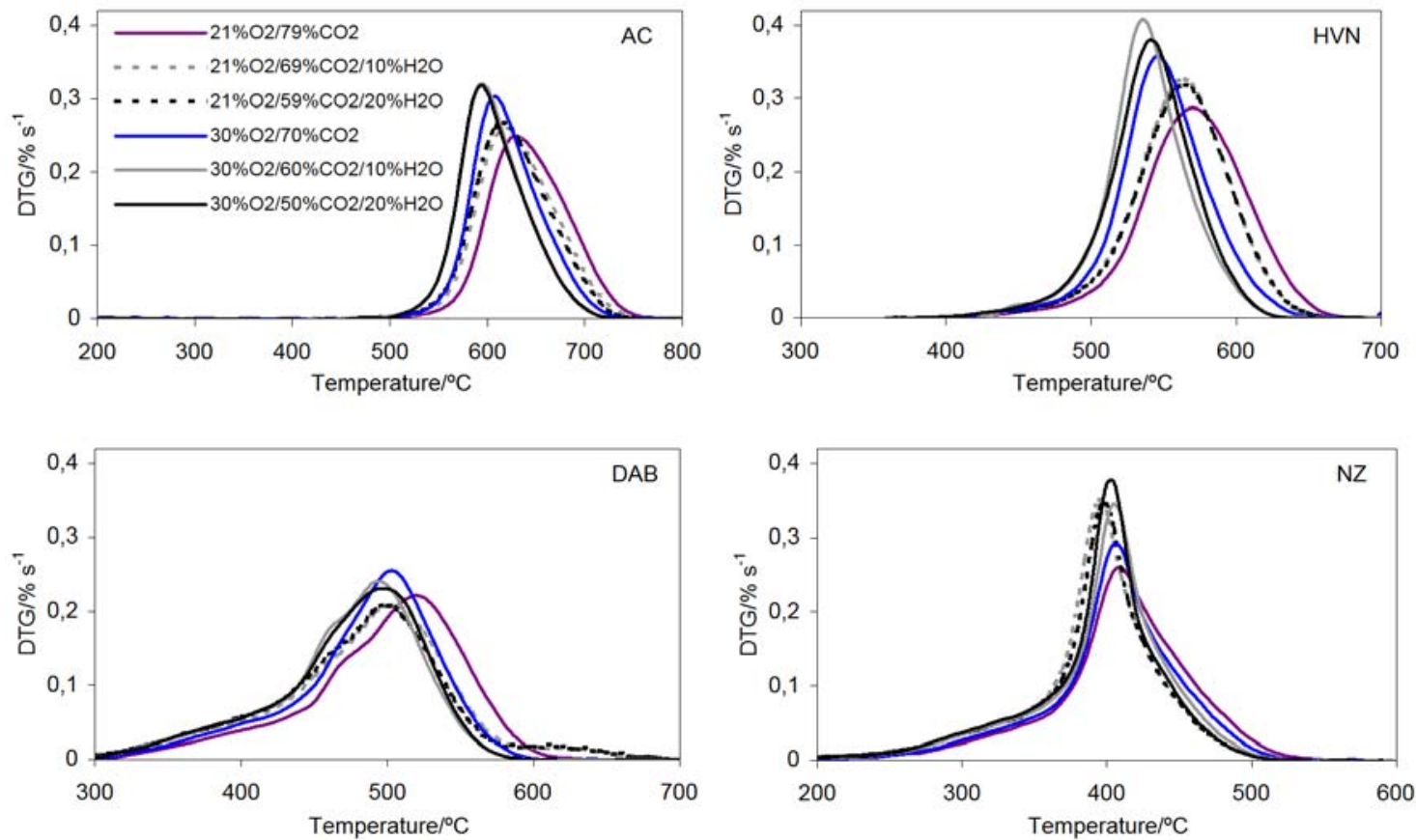

Fig. 3. DTG curves for coal combustion under oxy-fuel atmospheres with 21 and 30\% of $\mathrm{O}_{2}$ containing steam 